\title{
A new species of Brachyloma and three new subspecies of $B$. daphnoides (Epacridaceae) from south-eastern Australia
}

\author{
J.T. Hunter and J.B. Williams
}

\begin{abstract}
Hunter, J.T. and Williams, J.B. (Botany Department, University of New England, Armidale, NSW, Australia 2351) 1994. A new species of Brachyloma and three new subspecies of B. daphnoides (Epacridaceae) from south-eastern Australia. Telopea 6(1): 1-7. Morphological and ecological studies of Brachyloma daphnoides (Smith) Benth. have revealed four taxa: one new species (B. saxicola J.T. Hunter) and three subspecies (B. daphnoides subsp. daphnoides, subsp. glabrum, and subsp. pubescens). The new species is restricted to the granite outcrops of the Northern Tablelands and North Coast of New South Wales, and has been observed growing sympatrically, without interbreeding, with the more widespread $B$. daphnoides.
\end{abstract}

\section{Introduction}

Three varieties have been recognised within Brachyloma daphnoides (Smith) Benth. B. daphnoides (Smith) Benth. var. latiusculum Blakely \& McKie was distinguished by having a taller habit, longer and wider leaves, larger bracts and sepals, and a longer corolla tube (Blakely \& McKie 1930). A major distinguishing feature of this taxon, not noted by Blakely and McKie, is the absence of the hairs or scales within the corolla tube that are a feature of the genus (Powell \& Makinson 1992). Maiden, in 1910, made the first reference to the lack of hairs, writing 'corolla quite glabrous inside in some' on one of the sheets held at NSW. Although this was written on the sheet of a B. daphnoides specimen with hairs, this indicates Maiden must have examined some specimens of $B$. daphnoides var. latiusculum.

B. daphnoides (Smith) Benth. var. glabrum Blakely was separated on the basis of leaf size, sometimes smaller flowers, smaller fruit, and strictly glabrous stems and leaves (Blakely 1941). These two varietal names, since they were first published, have been rarely used (Beadle 1980: 610). Considerable variation has been noted within $B$. daphnoides, much of which is inadequately described by these two varieties (Powell \& Makinson 1992).

A study of the infraspecific variation and autecology of B. daphnoides (Hunter 1992) has shown that none of the previously described infraspecific taxa has been properly delimited. From this analysis it was apparent that a new species could be distinguished and three subspecific entities could be justified from within the variation of this widespread species. Areas of overlap were found to occur in the distributions of the subspecific entities which may cause problems in their delimitation in such regions. Recognition of subspecific entities is seen as clarifying the variation shown: as variation was not shown to be clinal, characters chosen for delimitation were reliable where distributions did not overlap, while other characters were shown to be consistently restricted to taxa even in areas of overlapping distribution. This paper formalises the taxonomic conclusions of that study. 


\section{Methods}

Over one hundred populations were sampled from within Queensland, New South Wales and Victoria. At each site between five and twenty separate plants were taken from each population. Five measurements of 40 character states were measured (e.g. leaf length) or described (e.g. leaf shape) from each of the specimens sampled. Cluster analysis of this data was performed by the program CLUSTAN (Wishart 1987) to aid taxonomic conclusions. Selected specimens where also studied using a Jeol J.S.M.-35 scanning electron microscope. Herbarium material from NE and NSW was then used to supplement decision-making on status and distributions of the taxa identified.

\section{Taxonomy}

Brachyloma daphnoides (Smith) Benth.

Synonyms: Styphelia daphnoides Smith, A Specimen of the Botany of New Holland: 48 (1795); Lissanthe daphnoides (Smith) R. Br., Prodromus Florae Novae Hollandiae: 541 (1810).

Type: New Holland, Smith 48 (holo LINN; Smith Herbarium No. 297.17).

This species is widespread in south-eastern Australia. Study of specimens held at NE, NSW and in the field has indicated that a distinct taxon may be segregated at specific rank and three others discerned as subspecies. The new species is more closely allied to $B$. daphnoides than to any other members of Brachyloma. The three subspecies occupy distinct geographic areas in which they are true to the characters used here to separate them. However, areas of overlap do occur. The OrangeLithgow-Goulburn region of New South Wales is an area in which the three subspecies are known to have overlapping distributions. On analysis of populations, the variation here appears to be of hybrid swarms rather than that typically shown by clinal variation which might otherwise negate subspecific ranking. As with other members of the Epacridaceae, there is a transitional series from caducous bracts to mature leaves. The transitional bracts are often hairier, ciliate, multi-veined and obovate in shape. Therefore only mature leaves have been used for the descriptions of subspecific taxa.

Although B. daphnoides is reported to occur in Tasmania (Powell \& Makinson 1992), this appears to be erroneous. This report appears to be due to three specimens found at NSW. On close inspection by one of us (Hunter), two of these, which included vegetative and fertile material, were identified as Monotoca; the third was a multiple collection of fragments which showed features of the three subspecies discussed below. The collection details merely stated ' $B$. daphnoides apparently rare in Tasmania' and the locality as 'Tasmania'. As no other collections are known from Tasmania, it can be assumed that $B$. daphnoides does not occur there.

\section{Key to the subspecies of Brachyloma daphnoides}

1 Leaves glabrous, 2-19.5 mm, generally > $7 \mathrm{~mm}$, long; young stems glabrous or variously hairy; flowers white or with red markings.

2 Flowers white; young stems hispid to villous; leaves 2-19.5 mm long a. subsp. daphnoides 
$2^{*}$ Flowers with some red colouring, at least at corolla base and lobes when juvenile; stems glabrous to scabrous, rarely sparsely hispid; leaves $2-12 \mathrm{~mm}$ long

b. subsp. glabrum

$1^{*}$ Leaves scabrous to villous, $1.5-8 \mathrm{~mm}$, generally $<7 \mathrm{~mm}$, long; young stems hispid to villous; flowers always white c. subsp. pubescens

\section{a. Brachyloma daphnoides (Smith) Benth. subsp. daphnoides}

Synonym: Brachyloma daphnoides (Smith) Benth. var. daphnoides.

Type: As for species.

Young stem hispid to villous. Mature leaves 2.5-19 $\mathrm{mm}$ long, 1-4.5 mm wide, narrow to widely elliptic, obovate, rhombic or ovate, mainly acute but sometimes obtuse, darker above, ciliolate, mainly glabrous with scabrous indumentum towards the base adaxially or sometimes scattered along major veins; veins prominently raised abaxially. Bracts sometimes pubescent on the lower surface. Corolla white or cream.

Selected specimens: Queensland: Moreton: Noosa Heads, Davis, 17 Aug 1959 (NE 005647).

New South Wales: North Coast: Bonny Hills, Hunter 104-1, 31 Dec 1991 (NE 054738A). Central Coast: Upper Mangrove Cr, Hunter 97-1, 24 Dec 1991 (NE 055163A); Agnes Banks, Hunter 1001, 25 Dec 1991 (NE 055173A); Buxton, Hunter 34-1, 22 Sep 1991 (NE 053979A); Bomaderry, Hunter 35-1, 22 Sep 1991 (NE 053980A). Central Western Slopes: $26.7 \mathrm{~km}$ south of Merriwa on Merriwa/Wollar Rd, Hunter 25-1, 20 Sep 1991 (NE 053969A).

Victoria: Heyfield, Hunter 40-1, 23 Sep 1991 (NE 053985A); Lochsport, Hunter 39-1, 24 Sep 1991 (NE 053984A).

Notes: This subspecies occupies a distinct region and is distinguishable from the other subspecies by the combination of almost glabrous longer leaves, villous stems, and white flowers. A long-leaved form of B. daphnoides subsp. daphnoides occurs in areas to the immediate south of Sydney (Thirlmere, Mt Kiera, Bomaderry). This form also has denser stem indumentum than specimens from other areas. Leaf length. in general decreases north and south from this area.

Distribution: Mainly restricted to the coast and hinterland from central Queensland (Yeppoon) south to East Gippsland, Victoria (Lochsport). Also extending to the Leichhardt district of central Queensland (Carnarvon), the Central and Southern Tablelands of New South Wales (Lithgow and Braidwood) and the Central Western Slopes of New South Wales (Merriwa).

Habitat: Open situations on well drained sites, predominantly on north- to eastfacing aspects. Mainly in dry sclerophyll forests but also occurring in other sclerophyll subformations. It is commonly found on coastal sands, but also on a variety of other soil types including medium heavy clay.

Etymology: The name daphnoides alludes to the Daphne-like scent of the flowers that is released at anthesis.

b. Brachyloma daphnoides (Smith) Benth. subsp. glabrum (Blakely) J.T. Hunter, comb. et stat. nov.

Basionym: Brachyloma daphnoides (Smith) Benth. var. glabrum Blakely, Contrib. New South Wales Natl. Herb. 1: 124 (1941).

Type: New South Wales: Murrumbidgee district, T. Duff, 1882 (holo NSW)

Glabrous to scabrous shrub. Mature leaves 2-12 $\mathrm{mm}$ long, 1-5.5 $\mathrm{mm}$ wide, narrow to widely elliptic, lanceolate, ovate to obovate or oblong, darker above, glabrous or 
sometimes ciliolate. Corolla white to cream always with red at least on the lobes and base.

Selected specimens: Queensland: Darling Downs: Stanthorpe, Hunter 76-1, 12 Oct 1991 (NE 054020D).

New South Wales: North Coast: Gibraltar Range, J.B. Williams, Sep 1960 (NE 024065); Northern Tablelands: $9.6 \mathrm{~km}$ north east of Torrington, Hunter 83-1, 13 Oct 1991 (NE 054029A); $15.5 \mathrm{~km}$ east of Backwater on Paddy's Gully Rd, Hunter 8-1, Aug 1991 (NE 053799A). Southern Tablelands: Tumut, Breakwell, Oct 1912 (NSW). Central Western Slopes: Temora, Bishop Dwoyer, Oct 1914 \& Oct 1915 (NSW); 3.7 km south-west of Temora on Moroney's Lane, Hunter 60-1, 27 Sep 1991 (NE 054005A). South Western Slopes: Albury, Frauenfelder, Sep 1917 (NSW); Albury, Rothery, Nov 1939 (NSW); Albury tip, Hunter 56-1, 27 Sep 1991 (NE 054001A).

Victoria: Chiltern, Staer, Sep 1911 (NSW); Mt Abrupt, Williamson, Oct 1901 (NSW); 12.5 km north of Huntly, Hunter 51-1, 26 Sep 1991 (NE 053996A); $5 \mathrm{~km}$ west of Kooreh, Hunter 49-1, 26 Sep 1991 (NE 053994A); Mitre, Hunter 46-1, 25 Sep 1991 (NE 053996A); Wartook, Hunter 44-1, 25 Sep 1991 (NE 053989A); Mt Cole, Hunter 41-1, 25 Sep 1991 (NE 053989A).

Notes: The red pigmentation of the corolla is restricted to this subspecies and always occurs. The amount of pigmentation can vary within and between populations and on the same plant. It becomes restricted to the base of the corolla tube and to the tips of the corolla lobes as the flower matures. The density of indumentum cover is a variable feature amongst populations and to a lesser extent within populations. However, leaves are always almost glabrous. The plants become more scabrous than glabrous away from the main centres of distribution (western to central Victoria and the Northern Tablelands of New South Wales). The geographic distribution of this taxon is distinct from that of the other subspecies. This subspecies is readily separated from the other subspecies by the red pigmentation on at least part of the corolla (although this may be hard to distinguish on dry specimens), the more elliptical shape of the leaves and the sparser indumentum on both the leaves and the stems.

Distribution: The distribution is disjunct. The major occurrence is within western (Mt Arapiles) and central Victoria (Greta) and south-central New South Wales (Holbrook); the other is on the Northern Tablelands (Armidale, Tenterfield), the North Coast (Gibraltar Range) and the North Western Slopes (Howell, Goonoowigall) of New South Wales.

Habitat: Most often in dry sclerophyll forest but also in many other sclerophyll structural subformations. Mainly in open situations on well drained sites, often on hill slopes. Victorian populations often grow with Grevillea alpina, Hibbertia stricta, and Astroloma conostephioides. Northern populations often grow with Eucalyptus caliginosa, Leucopogon melaleucoides, and Monotoca scoparia. This subspecies occurs on various soil types from sandy to medium heavy clay.

Etymology: The epithet glabrum refers to the relatively glabrous nature of this species by comparison with the other two subspecies.

c. Brachyloma daphnoides (Smith) Benth. subsp. pubescens J.T. Hunter subsp. nov.

Subsp. daphnoidi affinis; folia 1.5-8 mm longa, late elliptica vel elliptica, ovata vel circulares, scabrida vel villosa, minus adaxialiter; interdum hirtistyla.

Type: New South Wales: North Western Slopes: Yearinan State Forest, $5 \mathrm{~km}$ northeast of Bugaldie, Rock Crossing Rd, alt. 650 m, Hunter, 31 July 1991 (holo NSW; iso NE).

Hairy shrub. Stem indumentum hispid to villous. Corolla white. Style hairy in some. Mature leaves $1.5-8 \mathrm{~mm}$ long, $1-4.5 \mathrm{~mm}$ wide, widely elliptic to elliptic or ovate to orbicular, villous to scabrous, less so adaxially. 
Selected specimens: New South Wales: North Western Plains: $1.5 \mathrm{~km}$ north of Yetman, Hunter 73-1, 12 Sep 1991 (NE 054018A); Pilliga East State Forest, Brandons Rd, 2 km east of Newell Hwy, Hunter 20-1, 31 Aug 1991 (NE 053808A). North Western Slopes: Wittebra State Forest, Black Pine Rd, $5.9 \mathrm{~km}$ north of junction with Rocky Rd, Hunter 18-1,31 Aug 1991 (NE 053807A); $8.7 \mathrm{~km}$ south west of Coonabarabran on the Mendooran Rd, Hunter 85-1, 7 Dec 1991 (NE 055174A). Central Western Slopes: $3.5 \mathrm{~km}$ south-west of Mendooran on the Dubbo Rd, Hunter 87-1, 7 Dec 1991 (NE 053184A).

Notes: The leaves are scabrous from Narrabri to Wallangra where the soils become heavier. This also occurs south of Dubbo where the distribution overlaps with $B$. daphnoides subsp. glabrum. Flower colour always remains white. The style is hairy only in the most northern populations (Yetman). The new season stems are almost always villous. This subspecies is readily distinguished by the combination of overall hairiness (both stems and leaves) that often gives the plant a glaucous appearance, white flowers and the reduced leaf size. This subspecies has a well-defined distribution within the Pilliga region of New South Wales and is the most restricted and least variable of the $B$. daphnoides subspecific entities. Some specimens from the Southern Tablelands of New South Wales also appear to conform to the variation shown in this subspecies (i.e. hairy leaves and white flowers). This appears to be due to the overlap of all subspecies within this region and subsequent formation of hybrids.

Distribution: The main populations occur in the Pilliga region State Forests in the North Western Slopes of New South Wales, with some extensions into the Central Western Slopes (Mendooran) and North Western Plains (Pilliga, Yetman).

Habitat: Found mainly in dry sclerophyll forest in the Pilliga region of New South Wales. Commonly in open situations on well drained sites, often on hill slopes. Commonly found growing in association with Eucalyptus dealbata, E. crebra, and Callitris glaucophylla. Styphelia triflora, Melichrus urceolatus, Platysace ericoides, Acacia buxifolia, and Macrozamia spp. are often found in the understorey of these communities. Soils are mainly clayey sand.

Etymology: The epithet pubescens refers to the overall hairiness of this shrub by comparison with the other two subspecies.

\section{Brachyloma saxicola J.T. Hunter sp. nov.}

Affinis Brachyloma daphnoidi (Smith) Benth. a qua corollis glabris intus, semper albis, foliis 4-12 mm longis, 1.5-5 mm latis, laminis glabris vel scabris supra versus basin, habitu ad 4 metra alta, stylis $2-3 \mathrm{~mm}$ longis papillosis et fructibus globosis, differt.

Type: New South Wales: Northern Tablelands: Wattleridge, Backwater, J.T. Hunter, 2 Nov 1991 (holo NSW; iso NE)

Synonym: Brachyloma daphnoides (Smith) Benth. var. latiusculum Blakely \& McKie, Proc. Linn. Soc. New South Wales 55: 589 (1930). Type: New South Wales: Northern Tablelands: Pheasant Mtn near Backwater, Guyra, Blakely, McKie \& Youman (holo NSW).

Bushy, erect shrub to c. $4 \mathrm{~m}$ high. Leaves 4-21.4 mm long, 1.5-5 mm wide, oblanceolate or narrow elliptic to oblong, thick, flat, acute; leaf margin entire, upper margin sometimes serrulate; blade dark green above, lighter below, mainly glabrous, or adaxial surface scabrous towards the base. Petiole c. $1 \mathrm{~mm}$ long, villous. Flowers white to cream, towards the base of current season's growth; peduncle villous, c. 1 $\mathrm{mm}$ long; bracts leaf-like, mostly surrounding flowers, caducous; bracteoles strongly keeled, ciliate, 2-3 mm long. Sepals ciliate, 3-4 mm long; corolla tube constricted below the lobes, cylindrical, 2-3 $\mathrm{mm}$ long, papillose, lobes triangular 1.5-2 $\mathrm{mm}$ long, 
densely papillose all over; anthers papillose, red. Ovary waxy above, 5-celled; style 2-3 mm long, papillose. Fruit globose, 3-4 mm high, 4-5 $\mathrm{mm}$ wide, with ridged surface.

Selected Specimens: New South Wales: North Coast: Gibraltar Range, J.B. Williams, 1960? (NE 044553, NE 044554 \& NE 044555), J.B. Williams, 4 Aug 1961 (NE 024061), J.B. Williams, 25 Sep 1976 (NE 050208); Chaelundi Mtn, Hunter 155a, 27 Aug 1993 (NE 024065A). Northern Tablelands: $9.6 \mathrm{~km}$ north of Torrington, J.B. Williams, 3 Nov 1969 (NE 021907); $0.4 \mathrm{~km}$ north of Torrington, J.B. Williams, 19 Nov 1972 (NE 044965); $0.3 \mathrm{~km}$ north west of Torrington, Hunter 841, 13 Oct 1991 (NE 054030A); $0.4 \mathrm{~km}$ south-west of Torrington, Hunter 79-1, 13 Oct 1991 (NE 054024A); $3 \mathrm{~km}$ south of Torrington, Hunter 82-1, 13 Oct 1991 (NE 054027A); Bolivia Hill, J.B. Williams, 1 Jul 1971. (NE. 044377); Bolivia Range, J.B. Williams, 7 Jan 1984 (NE 051386); Mt Jondol, Hunter 1968 \& Clarke, 26 May 1994 (NE), Crown Mtn, Hunter 1804, 9 Mar 1994 (NE), Goat Ridge, Backwater, Hunter, 21 Aug 1991 (NE 053810A-H); Riley's Caves, Backwater, Hunter, 15 Dec 1991 (NE 054031A-X); Mushroom Rock (Pheasant Mtn), 3 km east of Backwater, J.B. Williams, 11 Oct 1971 (NE 027689).

Notes: Similar to $B$. daphnoides but differing in having a larger habit. The leaves of $B$. saxicola are larger and distinctly oblanceolate. Sepals and bracteoles are also larger. The fruit is larger and rounder. The inner corolla tube contains no hairs or scales, separating this species from all others in the genus. The corolla lobes are papillose all over instead of the papillae being restricted to the corolla lobes. Furthermore, the anthers are much more papillose. Although this species is separated ecologically from $B$. daphnoides, it often grows sympatrically (within less than a metre) with B. daphnoides subsp. glabrum at Torrington, Gibraltar Range and Backwater, with no intermediates being found at any locality. The flowering times of the two species are separated by at least one month. This species can be easily distinguished from the sympatric $B$. daphnoides subsp. glabrum by its size, the possession of entirely white flowers and villous stems.

Distribution and conservation status: Brachyloma saxicola is endemic to the granite areas of northern New South Wales. It has a highly restricted and disjunct distribution. It is only known from seven areas: Backwater, Crown Mtn, Mt Jondol, Torrington, Gibraltar Range, Mt Bolivia and Mt Chaelundi. These occurrences fall within Gibraltar Range National Park, Guy Fawkes River National Park, Crown Mountain Flora Reserve, Torrington Regional Trust Reserve, and a private reserve at Backwater. Williams and Wissmann (1991) have suggested the ROTAP code 2VC (Briggs \& Leigh 1988) for this species.

Habitat: This species is restricted to the upper parts of granite slopes and tor fields. It grows predominantly along drainage lines at the edges of exposed granite slopes and around granite boulders. The acidic soil is very skeletal, consisting mainly of organic matter.

Etymology: Named from the Latin saxum, stone, rock, and -cola, dweller, in reference to its restricted occurrence amongst granite boulders.

\section{Key to Brachyloma section Lissanthoides}

1 Corolla tube without 5 tufts of reflexed hairs B. saxicola

$1^{*}$ Corolla tube with 5 tufts of reflexed hairs

2 Corolla tube as long as sepals, $2-3 \mathrm{~mm}$ long, lobes longer than the tube, corolla tube and lobes papillose; leaves linear-lanceolate, pungent pointed, 8-15 mm long B. depressum

2* Corolla tube longer than the sepals, 3-4 mm long, lobes shorter than the tube 
3 External corolla tube and lobes papillose; leaf margins ciliolate, leaves 5$10 \mathrm{~mm}$ long, oblong to lanceolate, shortly pointed; small shrub to $20 \mathrm{~cm}$ tall

B. ciliatum

$3^{*}$ External corolla tube smooth, lobes papillose only on the lower half adaxially; leaf margins serrulate, leaves $2-19.5 \mathrm{~mm}$ long, mainly elliptic, tip with a short callous; shrub to $180 \mathrm{~cm}$ tall B. daphnoides

\section{Acknowledgements}

We are grateful to Brian and Judy Humphreys for allowing much work to be carried out on their property, Wattleridge. We also wish to thank Mike Henderson for spending so much time processing specimens. John Hunter gratefully acknowledges receipt of a N.C.W. Beadle Scholarship. Dr Barbara Briggs is also thanked for allowing access to the National Herbarium of New South Wales.

\section{References}

Beadle, N.C.W. (1980) Students Flora of North Eastern New South Wales, vol 4. (University of New England Press: Armidale).

Blakely, W.F. (1941) Additions to the Australian Flora. Contrib. New South Wales Natl. Herb. 1: $120-124$.

Blakely, W.F. \& McKie, E.N. (1930) Additions to the Flora of New England, N.S.W. Proc. Linn. Soc. New South Wales 55: 588-589.

Briggs, J.D. \& Leigh, J.H. (1988) Rare or Threatened Australian Plants. Australian National Parks and Wildlife Service. Special Publication No. 14, Canberra.

Hunter, J.T. (1992) Infraspecific variation of Brachyloma daphnoides (Smith) Benth. B.Sc. Honours Thesis, Botany Department, University of New England, Armidale, N.S.W.

Powell, J:M. \& Makinson, R. (1992) Brachyloma. Pp $432-433$ in G.J. Harden, (ed), Flora of New South Wales, vol. 3. (New South Wales University Press: Kensington).

Williams, J.B. \& Wissmann, H.J. (1991) Torrington Region, New South Wales: Checklist of Vascular Plants Occurring on the Mole Granite and Associated Rocks. Appendix H in G. Stewert, (ed), Torrington Region Draft Land Assessment (N.S.W. Dept. of Lands: Armidale).

Wishart, J (1987) CLUSTAN, version 3. (University of St Andrews: Fife). 